\title{
Assessment of Government Expenditure Management Practices: The Case of Oromia Police College, Oromia, Ethiopia
}

\author{
Mesfin Zewde ${ }^{1, *}$, Tadewos Mentta ${ }^{2}$ \\ ${ }^{1}$ Department of Accounting and Finance, Oromia Police College, Adama, Ethiopia \\ ${ }^{2}$ Department of Public Finance Management, College of Finance, Management and Development, Addis Ababa, Ethiopia
}

Email address:

mesfinzewde13@gmail.com (M. Zewde)

${ }^{*}$ Corresponding author

\section{To cite this article:}

Mesfin Zewde, Tadewos Mentta. Assessment of Government Expenditure Management Practices: The Case of Oromia Police College, Oromia, Ethiopia. Journal of World Economic Research. Vol. 9, No. 2, 2020, pp. 115-125. doi: 10.11648/j.jwer.20200902.16

Received: October 3, 2020; Accepted: October 28, 2020; Published: November 11, 2020

\begin{abstract}
The purpose of this study was to assess government expenditure management practice at Oromia Police College Procurement Finance and Property Management. Descriptive research method was employed to assess and describe assessment of government expenditure management practice in broad's importance. Primary data were collected by means of survey questionnaires from Oromia Police College (employees) police officers. Interviews were also conducted with police top management and Oromia Police employers Procurement Finance and Property Management. Focus group was discussion conducted with Oromia Police College Procurement Finance and Property Management employee and who were presently police costumes. In some developing countries a weak expenditure management process that have room for a magnified request, the spending is likely to be for less priority. In these circumstances, the best reaction would be to improve expenditure budget preparation. Since expenditure management is easy at budget preparation than later during the execution of the budget or this nonfiction discussed government expenditure management and practices in Oromia Police College. The problems and controversial issue related to government expenditure management and practices are reflected in the budget preparation, approval, execution, and audit phase of expenditure management practices. Therefore, the result of this study showed that there is a problem of linking the work plan with expenditure budget preparation. It is also revealed that purchasing of goods and services is not based on the annual action plan by organization. In other word, this indicated that there is a problem of budget preparation and execution. On the other hand, In relation to budget approval, the result of this study showed that Oromia Police College has effective systems of check and balance on government expenditure. The assessment was also undertaken to check auditor's satisfaction in relation to the support they get to conduct their task. The assessment result indicated that auditors have a problem of motivation with the financial and material support to carry out audit work to achieve their objectives. Thus, the study suggested that the program budgeting system introduced by the Oromia Regional Bureau of Finance and Economic Cooperation and Ministry of Finance and Economic Cooperation needs to be strongly considered to link the expenditure with the plan and implementation strategies.
\end{abstract}

Keywords: Government Expenditure Management Practice, Oromia Police College, Oromia, Ethiopia

\section{Introduction}

\subsection{Background}

The public sector of the economy, as a rule, established itself as a leading choice in the economy of developed countries. The effective functioning of this sector depends on qualified management; to make management decisions with respect to such organizations [1]. The role that government ought to play in the life of an economy is one of the most debated issues in the economic literature. Many models and frameworks have resulted in the quest for an adequate and sufficient explanation on the growth-expenditure nexus [2]. Several reasons account for this interest [3]. Public 
expenditure or public spending is a major component whenever strategies for stimulating economic growth and development are discussed [4]. To elaborate further that quality of government planners is essential for maximization of government efficiency thereby economic. The principal message with regard to the $\mathrm{s}$ hare of imports to total government expenditure is that fiscal policy makers should further be aware that the increase in imports is detrimental to real exchange rates and country's reserves especially when imports are financed by domestic financial resources; therefore countries should consider the significance instituting their own capacity to meet the government demand instead of relying much on importations for fast economic growth [5]. It should be noted that the most modern management technologies in the field of finance developed and proved to be successful in practice for commercial organizations. Commercial organizations are aimed at profit and welfare of its shareholders [6]. Government spending (or expenditure) is a tool to strengthen the capacities of people in health, education and income. It represents a key indicator in a country's growth and development [7]. The universal drive towards devolution has been increasingly justified on the basis that greater transfers of resources to sub national governments are expected to deliver greater efficiency in the provision of public commodities and accelerate development (Martinez county growth over time are not well understood. In particular, the effect of county expenditure on economic expansion has not been investigated exhaustively [8]. Transparency is a crucial element of sound management of military spending. States should maintain optimal or appropriate levels of military expenditure, based on a clearly established security policy, for several reasons [9]. The Fiscal management principles sought to improve the fiscal transparency through disclosure of sufficient information to allow the public to scrutinize the conduct of fiscal policy and the state of public finances. It has been acknowledged that the fiscal transparency in India has been high [10]. The traditional approach to public finance highlights three main fiscal policy function of government- allocation distribution, stabilization [11]. The fiscal outcomes for the central government during post FRBM Act shows that initial success in achieving the fiscal targets got disrupted due to the global financial crisis of 2008- 09 and since then there has been movements towards overarching macroeconomic stabilization process and overcoming the fiscal vulnerability [12]. The fiscal policy needs to respond to emerging socioeconomic issues and development requirement. The end of five-year development plan and the planning commission posed new challenges for the States to reorganize budget planning process [13]. In the context of fiscal policy and budgeting of the state governments, the contribution of various sectors to the state economy and possible revenue implication is important for which examining the macroeconomic outlook of a State becomes relevant [14]. Measures designed to improve transparency in military expenditure can be implemented by states at both international and national levels [15]. Access to information is essential for parliaments and civil society to ensure oversight and influence over the way in which the national budget, including the military budget, is spent [16]. Each pattern is linked with economic, security and political changes. First, in 1966-77 military expenditure almost quadrupled in real terms from $\$ 3.7$ billion to $\$ 14.4$ billion [17]. The military spending of most of the states involved in conflict rose substantially between 2014 and 2017. For example, the Democratic Republic of the Congo's (DRC) military expenditure rose by 29 per cent over the period. This growth was linked to continued political violence involving various militias in the provinces of North Kivu, South Kivu and Orientale [18]. States in conflict, or those with limited institutional capacity or that are considered to have a high level of corruption, tend to publish fewer military expenditure documents [19]. The State government adopted outcome budget to convert outlays to outcomes. This is based on the template provided in the Central outcome budget. The objective of the outcome budget to inculcate performance orientation in the budgeting system and influence the resource allocation based on the utilization of the performance information of the programs has not been served [20]. SIPRI has military expenditure information covering 2017 for 41 of the 47 states. For 38 of those states the information was gathered from official government budget documents [21]. The need for a medium term perspective as compared to a short horizon of an annual budget was the compelling reason behind the rapid expansion of this instrument [22]. The Central Government has taken lead in incorporating the medium term expenditure framework (MTEF) through the FRBM Act provisions [23]. The government expenditures are the expenses incurred for the maintenance of good governance in the interests of the society as well as the economy in general [24]. The objective of implementing public expenditure policy does not focus on promoting economic growth then efficiency ends-up at reducing the impact of government expenditure on economic growth [25]. Government expenditures include money spent on security, payment of salaries, payments for contracts, health care services, maintenance of law and order, and building of schools and provision of educational facilities [26]. Contention that market is not perfect, thus government intervention is required to minimize the distortions which results from market failure [27]. The increase in government expenditure fosters economic growth is influenced by various factors such as source of finance and efficiency to facilitate that spending [28]. Procurement is the central of public expenditure management. A well-organized, efficient and transparent public procurement system is a vital component of any sound PFM system and it transcends the budget process from procurement planning to audit [29]. In Africa, in order to improve efficiency in public expenditure management practices, there have been various reform programs in Public expenditure management, often entangled with reforms of the entire Public Financial Management. These reform programs in many African Countries including Ghana, Nigeria, South Africa and Kenya involved package of policy measures that included: Medium Term Expenditure Framework, 
Performance Based Budgeting (PBB), Financial Management Information System (FMIS) and Cash Management components of public expenditure management [30]. Every country's Government needs financial resources to carry out the responsibility assigned by its people. Specially, in public sectors, these financial resources can be raised by either through tax or non-tax instruments. To perform these, countries are advised to use public expenditure management and control systems in appropriate manner. Confers that Government expenditure in Ethiopia is increasing. Public expenditure management and control is a powerful tool in public financial management for allocating scarce resources to different programs [31].

\subsection{Statement of the Problem}

The expenditure focus largely reflects the close association between PFM and budgeting although PFM extends beyond this and could legitimately embrace all aspects of the management of public funds [32]. One of the important indicators of the quality of the PFM system is that the budget is realistic, and it is put into effect as intended. Respecting the sanctity of the budgetary provisions increases the credibility of government's policies [33]. The realization of budget surpluses over many years is a sign of good performance of the Congolese treasury system, but could hide systemic deficiencies. Indeed, the upstream strengthening of expenditure control at different stages of the chain of public expenditure (commitment, validation, authorization, and payment) reduces the accumulation of domestic arrears and also major delays in disbursement [34].

A good public expenditure management should consists of three key objectives namely, fiscal discipline (expenditure control); allocation of resources consistent with policy priorities ("strategic" allocation); and good operational management [35]. Despite all these debates, the argument whether government expenditure contributes positively to economic growth has become an accepted premise in most economies world over [36]. Along this hypothesis, for government expenditure to have significant contribution to the country's economic growth maximum efficiency in resources allocation is essential. The relationships between government expenditure and economic growth tend to vary and these variations are influenced by the level of efficiency [37]. The performance of government towards economic growth is more significant when government advances its accountability [38].

Government expenditure is an input which requires maximum efficiency in allocation so as to accelerate economic growth. Therefore growth maximization requires the attention of simultaneous magnitude of government expenditure and the level of government efficiency in resource allocation [39].

There is also a contention that in order to achieve robust results while analyzing the impacts of government expenditure on economic growth government efficiency should be considered [40]. Economic growth depends not only on government expenditure but also the ability of the government to allocate its public resources and therefore efficiency. Growth maximization requires a simultaneous awareness of government expenditure and efficiency [41].

In the case of Ghana, among various PFM reforms, there have been specific reforms in the areas of Budget and Public Expenditure Management System (BPEMS) from 2003-2007 which was re-launched into the Government Integrated Financial Management System (GIFMIS) Highlighting on some of the challenges of Ghana's public expenditure management, [42] reveals that, while expenditures have grown rapidly over the last four years, public revenues have remained essentially unchanged as a share of the GDP. Further, Ghana's expenditure levels in some core essential areas such as public health budget and human capital stock is modest as compared to the standards of other lower-middle-income countries [43]. Military spending does not necessarily translate in to improved national security, particularly in regions such as sub-Saharan Africa (SSA) that are strongly affected by security instability [44]. The military sector has been shown to be particularly prone to corruption, and information transparency is a tool for combating this problem [45]. While borrowing can case the trade off between spending and taxation it created its own problem [46].

The recent low level of volatility in spending is linked to the fact that states in Southern Africa are generally politically stable and have experienced almost no violent conflict (except Mozambique's civil conflict in 2013-14), [47]. In addition, South Africa has a diverse economy including a large financial services sector and is therefore not overly reliant on income from its natural resources (e.g. oil, copper and diamonds) to fund its military and non-military expenditures. Like South Sudan, the fall in oil prices has had a profound impact on Angola's military spending. The impact of low oil prices on Angola's economy may lead to further reductions in military spending [48]. Elsewhere in sub-Saharan Africa (SSA), violent conflicts are among the prime reasons for increases in military spending [49]. Mali's military expenditure rose by 152 per cent between 2014 and 2017, as it continued its fight against armed Islamist extremists. This was the largest increase in military expenditure by any state in sub-Saharan Africa (SSA), over the period [50]. While funding the military is a clear priority for governments in sub-Saharan Africa (SSA), the costs of prolonged conflict present serious problems [51]. In many developing countries, including Ethiopia, the integration of annual budgeting with medium term planning is fragmented. The main outputs of both reforms were limited to the documentation of the existing budget system. The preparation of public investment program. But the basic problems of resource allocation in the public sector are evolving to more complex forms related to the issues of policy and planning, aid management, performance budgeting, standardization and unit costing, monitoring and evaluation, reporting and accounting systems [52].

The more gap regional, Oromia Police Commission, as well as in Oromia Police College, since the internal auditor and external auditors are never isolated (independent) from certain office and composed in the same office and get their salary, the 
monitory budget and controlling an expenditure clearly is impossible. In this study the researcher attempted to see whether Oromia Police College finance and economic development bureau expend the budget effectively out standing on transparency of budget, up grading skill of internal audit, asset administration and no responsibility giving position without department. This study was considering factors that affect effectiveness of expenditure and related problem and provide possible solution for the problem identified.

Although efforts have been done and also being done to tackle the problem of government expenditure management practice, governmental expenditures are increasing in any organization at a faster rate and the governmental is losing a large number of its budget, which was continued up to these days. Furthermore, the study of assessing government expenditure management practice is relatively new area of engagement in the Oromia Police College in particular. Therefore, there is an evidently wide room for addition investigation. Thus, it is very important to study the real problem practice in Oromia Police College East Shoa Zone in Adama. Consequently, the purpose of this study is to examine the factors and impact of government expenditure management practice of Oromia Police College and to forward suggestions for solutions and provide recommendations.

As argument noticeably asserted in the above paragraph and the literature of different researches undertaken in other countries on this area forwards an implication as understanding the underlying relationship between government expenditures management practice is essential for devising and implementing policies. Coincident with the above fact, the distinct feature of this study is that it tried to investigate practice of government expenditures management on Oromia Police College which is expected to bridge the existing gap in the area of the study.

\section{Research Design and Methodology}

\subsection{Description of the Study Area}

This study was conducted in Oromia Police College. The college is located in East Oromia, East Shoa Zone, Adama City. Adama is found $99 \mathrm{kms}$ far from AddisAbaba, the capital city of Ethiopia.

Shoa astronomically the city is located from $8.140 \mathrm{~N}$ to $8.440 \mathrm{~N}$ and from $39.040 \mathrm{E}$ to $39.250 \mathrm{E}$. The city is boundedin the North bounded by Minjar woreda/district/ in the North, by Boset woreda in the East, by Lomme woreda in the West, and to the south bounded by Arsi Zone (Adama Woreda Agricultural Office report, 2013).

Adama is one of the major cities in Oromia regional State. It has now decentralized its authority to 14 urban and 4 rural Kebele administration totally 18 kebeles of the city to facilitate the basic activities so as to reach relevant public service at all levels.

Oromia Police College was established by 2002/ E.C.
Before the establishment of the college the regional police were trained in Oromia Police Training Centre which is currently called recruit and professional police training center and structured as three branches.

Since its establishment, the college has taken the responsibility of producing qualified and professionally skilled police officers who are ethically qualified to deliver police professional service for the community of the region. From the time of its inauguration, the college had graduated first round community police officers at diploma level in collaboration with Ethiopian Police University College. The College had also graduated Advanced Degree in Crime Prevention for the first time and Regular Diploma, Community Policing Diploma program officers in police science. The college is still providing training in regular police science degree program, different diploma programs.

\subsection{Research Design and Approach}

Research design essentially refers to the plan or regards the development of modern technology as providing a multitude of opportunities for innovative research design and advanced procedures in social sciences [53]. Mixed approach has been described in a variety of ways which can make it a difficult concept to understand [54]. Comment that this approach enables a greater degree of understanding to be formulated than if a single approach were adapted to specific studies [55]. Descriptive survey research method was conducted in Oromia Police College, Oromia, Ethiopia, in November, 2018 [56]. A mixed approach methods design is useful to capture the best of both quantitative and qualitative approaches.

\subsection{Types of Data and Sources}

Both primary and secondary data were used to conduct the research.

\subsection{Tools of Data Collection}

Data were collected using questionnaires, key informant interview, Observation, FGD and document analysis.

\subsection{Target Population}

All Oromia Police College workers who were selected based on purposive sampling from selected five sub departments (Procurement Finance and Property Management, Property management department and Human Resources Management Directorate, General Service Department, Internal Audit Directorate) constituted the study population.

\subsection{Sampling Techniques}

A sample size is defined as the subject or part of the entire population of the study from which we select a few objects (people) in the population for observation and then apply what was observed to the entire population of the study. The population of this study is a finite one. This made it possible for the researcher to use the following to solve in formula for determining the sample size [57]. To get the total number of 
target population, it is possible to add each target population in the following way:

Target populations taken from the Oromia Police College Procurement Finance and Property Management Directorate are forty two (42).

Target populations taken from the Oromia Police College Property management department are twenty five (25).

Target populations taken from the Oromia Police College Human Resources Management Directorate are ninety five (95).

Target populations taken from the Oromia Police College General Service are one hundred (100).

Target populations taken from the Oromia Police College Internal Auditors Five (5).

The total target population of the study can be the sum total of each target populations of Oromia Police College Procurement Finance and Property Management, Oromia Police College Property management, Oromia Police College human resources management directorate and Oromia Police College internal auditors directorate. Therefore, the total target population of the study is $42+25+95+100+5=267$.

$$
\mathrm{N}=\frac{\mathrm{N}_{-}}{1+\mathrm{N}(\mathrm{e})^{2}}
$$

Where:

$\mathrm{n}=$ is sample

$\mathrm{N}=$ total population

(e) $=0.05$ or allowance of random error

Therefore, to find the total sample (n) let's calculate based on the above formula

$$
\begin{aligned}
N & =\frac{267}{1+267(0.05)^{2}} \\
& =\frac{267}{1+267(0.0025)} \\
& =\frac{267}{1+0.667} \\
& =\frac{267}{1.667} \\
& =160
\end{aligned}
$$

In order to get the sample proportion of each stratum the

\begin{tabular}{|c|c|c|c|c|}
\hline No & Target population & Number & Percent\% & Sample \\
\hline 1 & Oromia Police College Procurement Finance and Property Mgt directorate & 42 & $60 \%$ & 25 \\
\hline 2 & Oromia Police College Property management department & 25 & $60 \%$ & 15 \\
\hline 3 & Oromia Police College Human resources management & 95 & $60 \%$ & 57 \\
\hline 4 & Oromia Police College General service employees & 100 & $60 \%$ & 60 \\
\hline \multirow[t]{2}{*}{5} & Oromia Police College internal Auditors directorate & 5 & $60 \%$ & 3 \\
\hline & Total & 267 & $100 \%$ & 160 \\
\hline
\end{tabular}
researcher used the following formula i.e. Sample proportion $(\%)=\mathrm{n} / \mathrm{N}=160 / 267=0.60(60 \%)$. By using sample proportion, the researcher computed each stratum sample size and the result is presented in the following table.

Table 1. Proportion of Sample Size.

Source: Field Survey, November, 2018.

The questionnaires were distributed to the total sample of 160 respondents based on purposive sampling techniques of probability sampling. The researcher selected the respondents based on their knowledge about expenditure management process.

\subsection{Data Collection Procedures}

The quantitative data were collected using a structured questionnaires adapted from different relevant studies. The questionnaire was first developed in English and then translated into Afan Oromo with some modification from the relevant sources. It was translated back to English by different language experts to check for consistency and then back to Afan Oromo to make interview with local respondents.

\subsection{Methods of Data Analysis}

The quantitative data, which have been collected via questionnaires, were presented using tables and charts for interpretation in relation to the research questions. Descriptive statistics used by feeding the quantitative data in to statistical software program (SPSS-20) and analyzed it in frequency, percentage, mean and standard deviation, to examine the occurrence and variation by chart and table. Rating systems are for strongly agree - strongly disagree is rated as 1-5 respectively and for choose (a-e) rated 1-5 respectively. The qualitative data obtained from semi-structured interview, FGD and documentswere transcribed, edited and organized around the subtopics derived from the research questions.

\subsection{Ethical Considerations}

The ethical issue of the study was approved by the authorized Oromia State University department of Accounting and Tax. After explaining the study procedures for the study subjects, verbal consents were obtained from Oromia Police College Procurement Finance and Property Management Directorate, each Oromia Police College Procurement Finance and Property Management employees.

\section{Results of the Study}

The results are presented in respect to the assessment of government expenditure management practices: - The case of Oromia Police College Oromia, Ethiopia. The finding of this study also showed that there was statistically significant difference in the respondents' general backgroundand the study has analyzed the critical issues of current status of major 
government expenditure management practices at Oromia Police College.

Table 2. Gender Rate of Respondents.

\begin{tabular}{lll}
\hline Gender of Respondents & Frequency & Percent \\
\hline Male & 144 & 90 \\
Female & 16 & 10 \\
Total & 160 & 100 \\
\hline
\end{tabular}

Source: Field Survey, November, 2018.

As indicated in Table 2; a total of male respondents were 144 representing $90 \%$, while 16 respondents were female representing $10 \%$ and total respondents for both sex were 160 representing $100 \%$. In these representations it revealed that in all categories of the respondents' male had higher frequency of respondents. This implies that the over whelming number of respondents were male. The main reason for the lower member of female respondents in this study goes to the historical gender disparity in the country in general and that of the region in particular. In addition, a total of seven key informants were participated and three FGDs were managed. However the questionnaires were distributed to the total sample of 160 respondents based on purposive sampling techniques of probability sampling. The researcher selected the respondents based on their knowledge about expenditure management practices.

Table 3. Data Analysis related to budget preparation and formulation stages.

\begin{tabular}{|c|c|c|c|c|c|c|c|c|c|c|c|c|c|c|c|}
\hline \multirow{2}{*}{ No } & \multirow{2}{*}{$\begin{array}{l}\text { Respondents } \\
\text { of issues }\end{array}$} & \multicolumn{2}{|c|}{ Strongly Agree } & \multicolumn{2}{|c|}{ Agree } & \multicolumn{2}{|c|}{ Neutral } & \multicolumn{2}{|c|}{ Disagree } & \multicolumn{2}{|c|}{ Strongly Disagree } & \multicolumn{2}{|c|}{ Total } & \multicolumn{2}{|c|}{ Mean \& Std. D } \\
\hline & & $\mathbf{F r}$ & $\%$ & Fr & $\%$ & Fr & $\%$ & $\mathbf{F r}$ & $\%$ & $\mathbf{F r}$ & $\%$ & Fr & $\%$ & Mean & Std. D \\
\hline \multirow[t]{2}{*}{1} & Budget manage & (offi & sent th & tual $\mathrm{f}$ & nd neec & (cap & 1 and $r$ & urren & dget). & & & & & & \\
\hline & & 15 & 9.4 & 30 & 18.8 & 29 & 18.1 & 51 & 31.9 & 35 & 21.9 & 160 & 100 & 3.38 & 1.18 \\
\hline \multirow[t]{2}{*}{2} & Top manageme & t ove & and rev & fixed & asset. & & & & & & & & & & \\
\hline & & 57 & 35.6 & 35 & 21.9 & 24 & 15.0 & 14 & 8.8 & 30 & 18.8 & 160 & 100 & 3.05 & 1.78 \\
\hline \multirow[t]{2}{*}{3} & The college Bo & $\mathrm{rd} \mathrm{Se}$ & and ar & zed a & out the & locati & of bud & $t$ bef & approv & & & & & & \\
\hline & & 16 & 10.0 & 29 & 18.1 & 30 & 18.8 & 66 & 41.3 & 19 & 11.9 & 160 & 100 & 3.27 & 1.22 \\
\hline \multirow[t]{2}{*}{4} & Each transactio & reco & ystem & he col & ege foll & & & & & & & & & & \\
\hline & & 44 & 27.5 & 48 & 30.0 & 23 & 14.4 & 29 & 18.1 & 16 & 10.0 & 160 & 100 & 2.79 & 1.98 \\
\hline
\end{tabular}

$\mathrm{Fr}=$ Frequency and Percent

Source: Field Survey, November, 2018.

The results in Table 3 indicate that $60.1 \%$ percent of the college board seriously and analyzed neutral or disagreed that some percent of budget allocation before approval needed by mean score of 3.27 and 1.22 standard deviation for police officer respondents. Further results indicated that $57.5 \%$ percent agreed or strongly agreed that each transactions recording system needed by mean score of 2.79 and 1.98 standard deviation for police officer respondents. Similarly, $54.4 \%$ percent of the top management oversight and review fixed asset respondents strongly agreed or agreed needed by mean score of 3.05 and 1.78 standard deviation for police officer respondents. The postponements and delays of the budget manager (office) budget manager present the actual fund needed as shown in table 53.8\%, earlier have resulted in the inability to provide capital and recurrent budge needed by mean score of 3.38. and 1.18 standard deviation for police officer respondents.

As indicated on Table 3, the majority of Oromia Police College respondents rated for disagree from the three listed factors and agree for one factor. Consequently, the result of study from the sum of questionnaires respondents' opinion, interviewees and FGD shows that, Oromia Police College responsiveness is below the expectation of the expenditure management practice.

Favoring this finding (item 1); capital and recurrent budget data collected from budget committee by interviewee shows, Oromia Police College Procurement Finance and Property management directorate has a mismatch between the need and the availability of resources. Additional comments that were given by respondents indicated the College did not present the actual fund needed within their program outline. Sometimes the office request more funds for cost centers that were not really operational budget approval the legislature then discusses the budget which can be including hearings and votes by the legislative committees.

As indicated on (item 2); along with this finding, from budget committee by interviewee shows, that top management doesn't oversight and review fixed asset to protect fraud on expenditure management.

The qualitative data from FGD and information regarding the College Board seriously and analyzed about the allocation of budget before approval in Oromia Police College was also sought. The key informants illustrated that this simply shows the proposal presented to OPCBC's and approved by BOFEC (Bureau of finance and Economic Cooperation). In relation to this as indicated on the legislatures, BOFEC have the right to review, debate, in some cases amend and approve or reject the spending plan proposed by the executive and ultimately approve the budget but in OPC this is not practically applied. Since most of the legislatures have no ideas or awareness and confident to debate, influence the budget allocation and approve budget on timely basis (before the fiscal year or not) to assess the timeliness of budget approval questions were also raised to the budget committee. Favoring this finding (item 4), each transaction recording system of the college follows the GASB procedures were rated agree (below average) by member respondents. 
Table 4. Data Analysis related to Expenditure Management Practice.

\begin{tabular}{|c|c|c|c|c|c|c|c|c|c|c|c|c|c|c|c|}
\hline \multirow{2}{*}{ No } & \multirow{2}{*}{$\begin{array}{l}\text { Respondents of } \\
\text { issues }\end{array}$} & \multicolumn{2}{|c|}{ Strongly Agree } & \multicolumn{2}{|c|}{ Agree } & \multicolumn{2}{|c|}{ Neutral } & \multicolumn{2}{|c|}{ Disagree } & \multicolumn{2}{|c|}{ Strongly Disagree } & \multicolumn{2}{|c|}{ Total } & \multicolumn{2}{|c|}{ Mean \& Std. D } \\
\hline & & $\mathbf{F r}$ & $\%$ & Fr & $\%$ & Fr & $\%$ & Fr & $\%$ & Fr & $\%$ & Fr & $\%$ & Mean & Std. D \\
\hline \multirow[t]{2}{*}{1} & \multicolumn{15}{|c|}{ Rate of the administration of controlling the expenditures. } \\
\hline & & 13 & 8.1 & 43 & 26.9 & 29 & 18.1 & 45 & 28.1 & 30 & 18.8 & 160 & 100 & 3.23 & 1.983 \\
\hline \multirow[t]{2}{*}{2} & \multicolumn{15}{|c|}{ Existence of system to minimize factors that affect budget expenditure. } \\
\hline & & 13 & 8.1 & 43 & 26.9 & 40 & 25.0 & 37 & 23.1 & 27 & 16.9 & 160 & 100 & 3.14 & 1.24 \\
\hline \multirow[t]{2}{*}{3} & \multicolumn{15}{|c|}{ The status of college in terms of take control on every activities of expenditure. } \\
\hline & & 27 & 16.9 & 29 & 18.1 & 37 & 23.1 & 41 & 25.6 & 26 & 16.3 & 160 & 100 & 3.06 & 1.33 \\
\hline 4 & & 23 & 14.4 & 47 & 30 & 28 & 17.5 & 33 & 20.6 & 29 & 18.1 & 160 & 100 & 2.99 & 1.35 \\
\hline \multirow[t]{2}{*}{5} & \multicolumn{15}{|c|}{ As military the problem of government budget allocation. } \\
\hline & & 13 & 8.1 & 43 & 26.9 & 29.1 & 18.1 & 45 & 28.1 & 30 & 18.8 & 160 & 100 & 3.32 & 1.81 \\
\hline
\end{tabular}

$\mathrm{Fr}=$ Frequency and Percent

Source: Field Survey, November, 2018

Table 4 shows that, rate of the administration, control every activity of expenditure and as military the problem of budget allocation, (item 1, item 3 and item 5), duplicate respondents were rated disagrees by score $45(28.1)$ and 41 (25.6\%) respectively. The table shows $47(30 \%)$ and $43(26.9 \%)$ of the respondents were rated disagree both for item 2 and item 4 that minimize factors affecting budget expenditure and practice of government. Among others, the following are summarized from respondents' responses which are identified in open ended questionnaires and data collected by interviewer from budget hearing committee. These are: The heads of Oromia Police College management member (OPCMM) did not give much attention for preparation of budget and numbers of professionals (budget officers) in government institutions are not sufficient. The budget process is limited and OPCBC have lack of skill (capacity constraints) and information to influence and control over section government budget. As the interviewee indicated, there is no transparency on budget allocation process and there is no participatory process. The qualitative data from FGD illustrated that, the responsiveness of Oromia Police College is delayed and most of the time there are problems of government budget allocation processes in the College. The most important issue in government budget is how the government funds are allocated to each office or program. The efficiency criteria consider that resources should be allocated so as to maximize sector programs while government priority considers that budget should be allocated in accordance with its objectives. But it is possible to reconcile both programs by using budget reforms. Budget reforms such as planning, programming and budgeting are expected to handle both expenditures priorities and location's efficiency. The research findings and results have been showed several problems related to governmental budget allocation in Oromia Police College.

Table 5. Data Analysis related to effective expenditure management.

\begin{tabular}{|c|c|c|c|c|c|c|c|c|c|c|c|c|c|c|c|}
\hline \multirow{2}{*}{ No } & \multirow{2}{*}{$\begin{array}{l}\text { Respondents } \\
\text { of issues }\end{array}$} & \multicolumn{2}{|c|}{ Strongly Agree } & \multicolumn{2}{|c|}{ Agree } & \multicolumn{2}{|c|}{ Neutral } & \multicolumn{2}{|c|}{ Disagree } & \multicolumn{2}{|c|}{ Strongly Disagree } & \multicolumn{2}{|c|}{ Total } & \multicolumn{2}{|c|}{ Mean \& Std. D } \\
\hline & & Fr & $\%$ & Fr & $\%$ & $\mathbf{F r}$ & $\%$ & Fr & $\%$ & $\mathbf{F r}$ & $\%$ & Fr & $\%$ & Mean & Std. D \\
\hline \multirow[t]{2}{*}{1} & Effective imple & henta & f segre & $n$ of & ties $\mathrm{p}$ & $y$ and & cedure & & & & & & & & \\
\hline & & 8 & 5 & 24 & 15 & 49 & 30.6 & 47 & 29.4 & 32 & 20 & 160 & 100 & 3.29 & 1.86 \\
\hline \multirow[t]{2}{*}{2} & Internal auditor & comr & resourc & evel & ment $p$ & gram. & & & & & & & & & \\
\hline & & 13 & 8.1 & 33 & 20.6 & 41 & 25.6 & 39 & 24.4 & 34 & 21.3 & 160 & 100 & 3.30 & 1.87 \\
\hline \multirow[t]{2}{*}{3} & Authority give & dequ & 11 upgr & $\mathrm{g}$ tra & ng to & late th & ditor's & & & & & & & & \\
\hline & & 8 & 5 & 28 & 17 & 31 & 19 & 55 & 34.4 & 38 & 28 & 160 & 100 & 3.54 & 1.78 \\
\hline \multirow[t]{2}{*}{4} & Level of impler & enta & goverr & t $\mathrm{ex}_{1}$ & aditure & amew & in Coll & & & & & & & & \\
\hline & & 12 & 7.5 & 42 & 26.3 & 23 & 14.4 & 50 & 31.3 & 33 & 30.6 & 160 & 100 & 3.21 & 1.995 \\
\hline \multirow[t]{2}{*}{5} & Familiarity wit & gove & it polic & nd fi & al plan & & & & & & & & & & \\
\hline & & 9 & 5.5 & 28 & 17.5 & 41 & 25.5 & 40 & 25.0 & 42 & 26.3 & 160 & 100 & 3.49 & 1.73 \\
\hline
\end{tabular}

$\mathrm{Fr}=$ Frequency and Percent.

Source: Field Survey, November, 2018.

Concerning table 5; above (item 1 and 2), both effective implementation and internal Auditor respondents were rated neutral by score of $49(30.6 \%)$ and $41(25.6 \%)$ respectively. Both (Item 3 and 4) adequate auditors skill and framework respondents were rated disagree by score of 55 (34.4\%) and $50(31.3 \%)$ respectively. Other familiarity with government police and fiscal planning (item 5), weigh up a strongly disagree $42(26,3)$ respectively.

As indicated on table 5 (item 1), according to the findings of study from the sum of questionnaires respondents' opinion and interviewees shows that, the budget information provided for the College is not understandable and there is no availability of clear information on time. Lack of adequate information is one of the characteristics of weak budgeting systems. This usually begins with unreliable and late input information on expenditure and costs, which is crucial to decision making and effective expenditure control. Therefore, availability of clear information at the time basis is one of the crucial in budget transparency. However, regarding to this, questions were raised for respondents; whether there is clear 
information or not in Oromia Police College. Accordingly, most of the respondents replied that clear information was not available on the time.

The qualitative data from FGD illustrated that, the medium term expenditure framework approach is essentially an effective budget process. If properly implemented, the medium term expenditure finance can improve medium term resource allocation and creates the link between policies and programs, and the resources allocated to their implementation. However, Oromia Police College is not effective and doesn't implement linkage of government policy, plan and budget allocation to address and provide solution for the problems of expenditure management. Without implementing complementary planning and budget reforms, it is impossible to achieve the full benefit of the medium term expenditure program.

The study illustrated that, efficient implementation of government expenditure management practice in Oromia Police College. The measurement was on a Five - point rating scale (1- Strongly Agree Efficient, 2- Agree Efficient, 3Neutral, 4- Disagree Efficient, 5-Strongly Agree Inefficient). which were interpreted using most of the respondents percentage. The result is presented in figure 1. Majority were other holders which accounted respondents, representing 72 (45.4\%) of the official rating government expenditure practice at in Oromia Police College as agree efficient and 35 (21.8\%) strongly agree inefficient and 9 (5.4\%) responded strongly agree efficient. The other two responded $21(13.1 \%)$ in the same way.

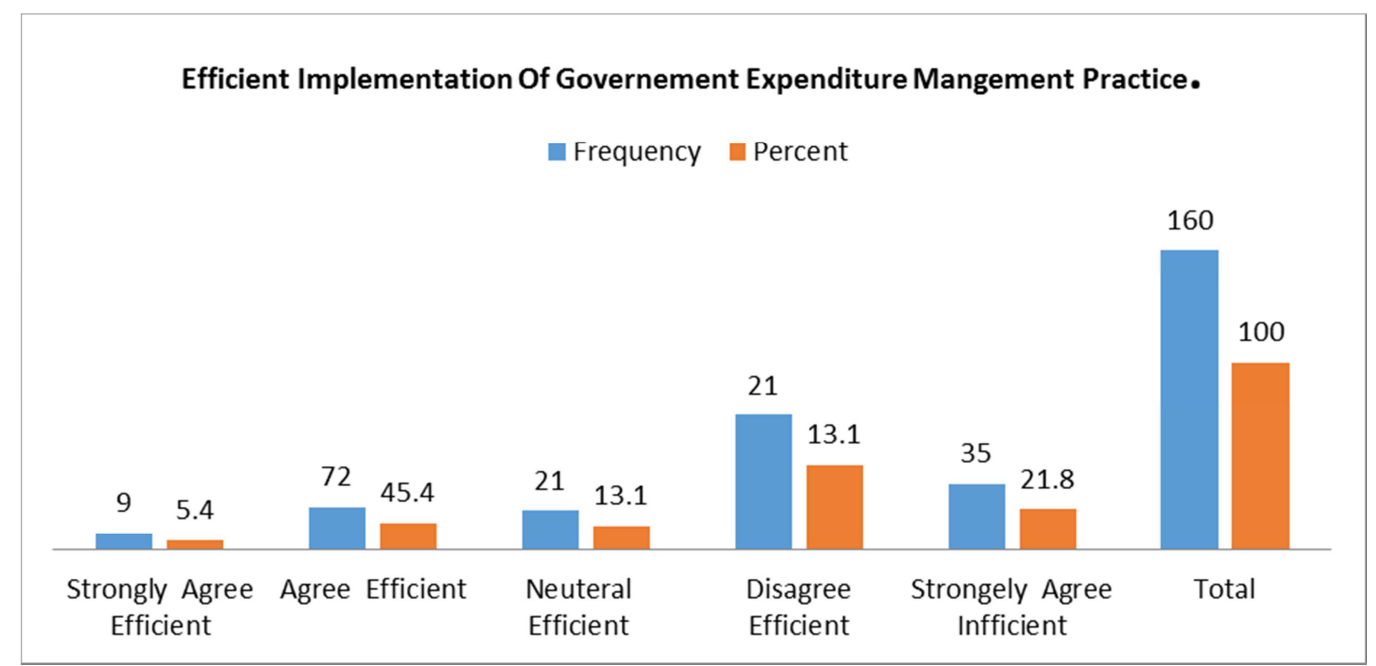

Figure 1. Efficient Implementation of Government Expenditure Management in OPC. (Source: Field Survey, November, 2018).

Information regarding the government expenditure management practices was also sought from key informant interviews. The key informants noted efficient implementation of government expenditure management practice in Oromia Police College is almost always not higher than that of development expenditure management.

Favoring this finding FGD indicated that, the responsiveness of Oromia Police College is beneath the expectation of Procurement Finance and Property Management employees and they didn't give much attention for expenditure management practice and the budget information provided by the College was not understandable.

\section{Conclusions}

This study provides a discussion and conclusion about the overall research problem and provides a conclusion to the whole research effort. The study has tried to explore the existing situation on government expenditure management practices of Oromia Police College. To conduct this study data was collected through questionnaires, interview, FGD and secondary data analysis. The collected data were carefully analyzed using qualitative and quantitative data analysis approaches.
Government expenditure management and practice is an activity that consists of the preparation and approval of the budget by the legislature performance of the budget during the year and the final auditing by the auditor. Government expenditure management processes are not systems which is mechanically attempt by legal frameworks and rules once established. They are more likely natural processes comprises of different rules, regulations, approaches and methods over time.

In Oromia Police College budget preparation process is unsatisfactory. This is because each division as well as Oromia Police College Board of Committee did not seriously analyzed in preparing annual work plan based on government priorities before budget request. In relation to this, once the resource envelope is set and the College receives its share, directorate of plan doesn't consider the annual work plan and shape within the annual budget plan well. The legislatures have the right to review, debate, in some cases amend and approve or reject the spending plan proposed by the executive and also replace by their own subject matter. In practice, this is somewhat far from that provided above. The office legislatures had limitation in influencing budget priorities setting among different office, and amending or adjusting the allocated budget by 
executives. The Oromia Police College Board of Committee and internal auditor have capacity constraints and information to influence and control over government budget. This shows as there is a knowledge gap in the area of budget and budgetary process among OPC.

The Linkage between planning and budgeting: medium term expenditure finance was not prepared in the College to grate government policies and plans with available resource allocation. The linkage between government policies and fiscal planning processes with annual budget is inadequate. In Oromia Police College, government policies didn't accessibly and clearly articulated in each aspect and annual budget request is not really linked with their annual work plans. In terms of budget transparency, billboard posters are the dominant mechanisms used to disseminate budget information. On the other hand, to some extent budget information is provided in understandable form but, clear information is not available at the time bases in Oromia Police College. This is due to lack of adequate information, lack of giving more attention by the head of the College for budget preparation and lacks skills of human power.

\section{Recommendations}

Based on the study findings the following recommendations are drown to achieve effective government expenditure management practices of Oromia Police College.

Budget Preparation: to increase the chance of success and credibility of section government budget allocation, each division should prepare their annual work plan seriously by coordinating with Procurement Finance and Property Management Directorates. After budget expenditure planning is prepared, it should be submitted to Bureau of Finance and Economic Cooperation for approval. Therefore, a broad involvement of the College committee and different stakeholders in the process of expenditure planning is one of the most important factors to improve resource allocation in the College. This is because, of the College budget Committee do not approve it; it remains for the Bureau of Finance and Economic Cooperation (BOFEC's) technical document rather than a strategic planning and budgeting framework. Therefore, the BOFEC's directorate should improve the number of professionals (budget officers) in government institutions as well as improving their capacity by giving training on how planning and budgeting is formulated.

Budget Approval: The OPC as well as the Oromia region should strengthen the budgetary role of the legislative so that they will have a power to review and amend the budget in relation to priorities. On the other hand, as we have seen earlier, the Oromia Police College employees Procurement Finance and property management members have inadequate skills and information to influence and control over section government. Therefore, the members require supporting and training to ensure that they acquire knowledge on budgetary process and also the budget committee should have supported by expertise to work effectively on expenditure planning and annual budget allocation.
The Link between planning and budgeting: medium term expenditure firework is also a mechanism to resolve the conflict between what is affordable and what is demanded or needed. By linking budget firmly policies and development objectives, the medium term expenditure framework enables legislature, monitor governmental activities more defiantly. Accordingly, the regional government as well as the section government needs to develop real and full- fledged multiyear expenditure planning which includes recurrent and capital expenditure as well as aspect development programs and poverty reduction strategy.

Transparency: In terms of budget transparencybudget information is provided in understandable form. But, there is limitation regarding availability of clear information at the time bases in Oromia Police College. Therefore, OPC Procurement Finance and Property Management Directorates should increase availability of clear budget information provided at the timely bases in order to improve budget transparency in the College.

\section{References}

[1] Baubion C (2013) OECD Risk Management: Strategic Crisis Management. OECD Working Papers on Public Governance, no. 23. Paris: OECD Publishing. Available at: http://dx.doi.org/10.17 87/5k41rbd1lzr7-en.

[2] Abu-Eideh, O. M. (2015). Causality between Public Expenditure and GDP Growth in Palestine: An Econometric Analysis of Wagner's Law. Journal of Economics and Sustainable Development, 6 (2), 189-199.

[3] Ahmad, U. G., \& Suleiman, U. A. (2015). Revisiting the link between government spending and economic growth in the present of Wagner's Law in Nigeria. Journal of Economics and Finance, 6 (6), 56-64.

[4] Afonso, A., \& Jalles, J. T. (2014). Causality for the government budget and economic growth. Applied Economics Letters, 21 (17), 1198-1201.

[5] Wenyi Shen, Yang, S.-C. S. \& Zanna, L.-F, 2015. Government Spending Effects in Low-income Countries, WP/15/286, International Monetary Fund.

[6] Berryhill J, Bourgery T, Hanson A (2018) Blockchains Unchained: Blockchain Technology and its Use in the Public Sector. OECD Working Papers on Public Governance, no. 28. Paris: OECD Publishing. Available at: http://dx.doi.org/10.1787/3c32c429-en

[7] Afonso, A., \& Kazemi, M. (2017). Assessing public spending efficiency in 20 OECD countries. In B. Bökemeier \& A. Greiner (Eds.), Inequality and finance in macrodynamics. Dynamic modeling and econometrics in economics and finance (Vol. 23). Cham: Springer.

[8] Mutie N (2014). Effects of Devolved Funds on Economic Growth in Kenya: Empirical Investigation (1993-2012).

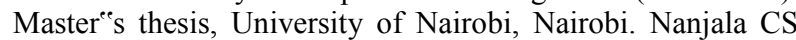
(2015). Explaining the Relationship between Public Expenditure and Economic Growth in Kenya using Vector Error Correction Model (VECM). International Journal of Economic Sciences 4 (3): 19-38. 
[9] Fan, H. L., Liu, W. and Coyte, P. C., 'Do military expenditures crowd out health expenditures? Evidence from around the world, 2000-2013', Defence and Peace Economics (2017); and Dunne, J. P. and Tian, N., 'Military expenditure and economic growth: a survey', Economics of Peace and Security Journal, vol. 8 , no. 1 (2013).

[10] Jena, Pratap Ranjan, (2010), India: Public Expenditure and Financial Accountability, Public Financial Management Performance Assessment Report, National Institute of Public Finance and Policy, New Delhi.

[11] R. Allen et al. (ends), International Handbook of Public financial Management (C) plagrave macmillan a.division of macmillan publishers limited 2013.

[12] Government of India, Ministry of Finance, 2018 Economic Survey 2017-18 PEFA, 2016. Framework for Assessing Public Financial Management, PEFA Secretariat Washington DC 20433, USA.

[13] Corbacho, Ana and Teresa Ter-Minassian, 2013. Public Financial Management Requirements for Effective Implementation of Fiscal Rules, In (eds.) Richard Allen, Richard Hemming and Barry $\mathrm{H}$. Potter, The International Handbook of Public Financial Management, 219-236. Palgrave Macmillan.

[14] In Jagdish Bhagwati and Arvind Panagariya, 2013, Why Growth Matters; The authors argue forcefully that economic growth, led by markets overseen and encouraged by liberal state policies would help the poor.

[15] Omitoogun, W., Military Expenditure Data in Africa: A Survey of Cameroon, Ethiopia, Ghana, Kenya, Nigeria and Uganda, SIPRI Research Report no. 17 (SIPRI: Stockholm, 2003); and Bromley, M. and Solmirano, C., Transparency in Military Spending and Arms Acquisitions in Latin America and the Caribbean, SIPRI Policy Paper no. 31 (SIPRI: Stockholm, Jan. 2012).

[16] Gorbanova, M. and Wawro, L., The Transparency of National Defence Budgets (Transparency International: London, 2011); and Broz, J. L., 'Political system transparency and monetary commitment regimes', International Organization, vol. 56, no. 4 (2002), pp. 861-87; and Tian and Lopes da Silva (note 6).

[17] All military spending figures are quoted in 2016 constant US dollars; Tian, N. et al., 'Military expenditure', SIPRI Yearbook 2017: Armaments, Disarmament and International Security (Oxford University Press: Oxford, 2017).

[18] Albalate, D., Bel, G. and Elias, F., 'Institutional determinants of military spending', Journal of Comparative Economics, vol. 40 (2012), pp. 279-90; and Dunne, J. P. and Perlo-Freeman, S., 'The demand for military spending in developing countries: a dynamic panel analysis', Defence and Peace Economics, vol. 14 , no. 6 (2003), pp. 461-74.

[19] Perlo-Freeman, S., 'The South African arms deal', A Compendium of Arms Trade Corruption, World Peace Foundation, 5 May 2017.

[20] No military expenditure was found for Djibouti (since 2008), Equatorial Guinea (various gaps, last in 2017), Eritrea (since 2003), Gambia (since 2016), Guinea-Bissau (since 2016), Mauritania (2017). The 2 countries not included in the SIPRI Military Expenditure Database are the Comoros and Sao Tome and Principe.

[21] Jena, 2016. Reform Initiatives in the Budgeting System in
India”, Public Budgeting \& Finance, Wiley-Blackwell, Spring, Vol. 36, Issue 1.

[22] Brumby, James and Richard Hemming. 2013. Medium-term Expenditure Frameworks, In (eds.) Richard Allen, Richard Hemming and Barry H. Potter, The International Handbook of Public Financial Management, 219-236. Palgrave Macmillan.

[23] Jena, 2018. Adopting MTEF through Fiscal Rules: Experiences of Multi-year Budget Planning in India, International Journal on Governmental Financial Management - Vol. XVIII, No 2.

[24] Adejoh, E., \& Sule, J. G. (2013). Revenue generation: Its impact on government developmental effort: a study of selected local council in Kogi East Senatorial District. Global Journal of Management and Business Research Administration and Management, 13 (4), 17-25. Retrieved from journalofbusiness.org

[25] Macek, R. \& Janků, J., 2015. The Impact of Fiscal Policy on Economic Growth Depending on Institutional Conditions, VSB-Technical University, Ostrava.

[26] Abba, M., \& Kakanda, M. M. (2017). Moderating Effect of Internal Control System on the Relationship between Government Revenue and Expenditure. Asian Economic and Financial Review, 7 (4), 381-392. https://doi.org/10.18488/journal.aefr/2017.7.4/102.4.381.392.

[27] Parker, D. \& Kirkpatrick, C., 2012. Measuring Regulatory Performance; The Economic Impact of Regulatory Policy: A Literature Review of Quantitative Evidence, Expert Paper No 3, OECD.

[28] Cakerri, L., Petanaj, M. \& Muharemi, O., 2014. The Effect of Government Expenditures on Economic Growth: The case of Albania. European Journal of Social Sciences, 2 (1), pp. 242-253.

[29] Pretarious C and Pretarious N. January 2009. Pubic Financial Management Reform Literature Review, Department for International Development, Evaluation Working Paper/Evaluation Report EV698.

[30] Scott, G. K. (2016). Influence of public financial management practices on service delivery: a case of District Assemblies of Ghana. Unpublished PhD Thesis. University of Cape Coast, Ghana.

[31] Alemayehu Geda, and Dawit Birhanu (2011), Spending without Proper planning: Why Ethiopian Agriculture is not Growing Despite High Public Spending in the Sector by Africa Standard, A Macro Perspective p. 84.

[32] Thus, the tax -reform literature is concerned the design of a tax system that meets economic and social objective and collects a desired amount of revenue while doing as little economic harm as possible. Tax design is discussed in chapter 19.

[33] PEFA, 2016. Framework for Assessing Public Financial Management, PEFA Secretariat Washington DC 20433, USA

[34] The Word Bank. 2013. "Review of the use of national public finance management system by the investment projects financed by the World Bank."

[35] Systems-An Experimental Methodology with an Application to the Australia and New Zealand Reforms; Revised: December 20, 1996, Published in the Journal of Policy Analysis and Management, Summer 1997. http://www1.worldbank.org/publicsector/anticorruption/Flags hipcourse03/CamposPradhan. 
[36] Prasetyo, A. D. \& Zuhdi, U., 2013. The Government Expenditure Efficiency towards the Human Development. Procedia Economics and Finance, 5, pp. 615-622.

[37] Rahmayanti, Y. \& Horn, T., 2010. Expenditure Efficiency and the Optimal Size of Government in Developing Countries, Discussion Paper 10-20, Osaka.

[38] Hauner, D. \& Kyobe, A., 2010. Determinants of government efficiency. World Development, 38, pp. 1527-1542.

[39] Therkildsen, O., 2010. Working in Neopatrimonial Settings : Perceptions of Public Sector Staff in Tanzania and Uganda, WP. No. 117, Johannes, Gutenberg.

[40] Avkiran, N., 2006 \& Mandl, U., Dierx, A. \& Ilzkovitz, F., 2008. Productivity Analysis in the Service Sector with Data Envelopment Analysis Third Edit., QLD 4072, Australia: UQ Business School, The University of Queensland \& the effectiveness and efficiency of public spending, Wconomic Papers 301, European Commission, Brussels.

[41] Angelopoulos, K., Philippopoulos, A. \& Tsionas, E., 2008. Does Public Sector Efficiency Matter? Revisiting the Relation between Fiscal Size and Economic Growth in a World.

[42] Adzroe, G. (2015). An overview of PFM reforms in Ghana. Presentation by the Controller and Accountant-General at the Labadi Beach Hotel during the IFAC Round Table Discussion on IPSAS from 21st-22nd May 2015.

[43] World Bank (2017). Fiscal consolidation to accelerate growth and support inclusive development: Ghana public expenditure review. Retrieved from documents. World bank.org.

[44] Baldacci, E. et al., 'Social spending, human capital, and growth in developing countries', World Development, vol. 36, no. 8 (2008), pp. 1317-41; and Perlo-Freeman, S., 'Military and social expenditure', SIPRI Yearbook 2016: Armaments, Disarmament and International Security (Oxford University Press: Oxford, 2016), pp. 520-34.

[45] Perlo-Freeman, S., 'Transparency and accountability in military spending', SIPRI Commentary, 3 Aug. 2016; and Bromley and Solmirano (note 7).

[46] There is an enormous literature on the link between fiscal policy and economic growth, looking at the impact of level and composition of spading, the level and structure of taxation and deficits and debt. Gernmell, kneller and sent (2011) discuss the theoretical and empirical issues that arise in trying tub establishing to establish the nature and significance of these links.

[47] Africa Center for Strategic Studies, 'Militant Islamist groups in Africa show resiliency over past decade', 28 June 2018.

[48] The World Bank, 'South Africa economic update', The International Bank for Reconstruction and Development, (World Bank: Washington, D. C., April. 2018).

[49] Global Witness, Capture on the Nile: South Sudan's State-owned Oil Company, Nilepet, Has Been Captured by the Country's Predatory Elite and Security Services, (Global Witness: London, Apr. 2018).

[50] Patrick, M., 'Angola cuts 2016 spending by 20\%', Wall Street Journal, 14 Mar. 2016; and Rumney, E., 'Angola passes revised budget as falling oil prices hit economic forecast', Public Finance International, 17 Aug. 2016.

[51] Armed Conflict Location and Event Data Project, 'Real-time analysis of African political violence', Conflict Trends Report no. 54 (Dec. 2016).

[52] Armed Conflict Location and Event Data Project, 'Real-time analysis of African political violence', Conflict Trends Report no. 54 (Dec. 2016). 25 Nuba Reports, 'A new conflict in Darfur, more displaced', Sudan Insider, 1 June 2017.

[53] Abebe Yusuf, (2016), Standard term expenditure and budgetary practice in Ethiopian.

[54] Creswell, J. W. (2014). Research Design: Qualitative, Quantitative and Mixed Methods Approaches (4th ed.). London: Sage Publications Ltd.

[55] Niglas, K. (2009). How the novice researcher can make sense of mixed methods designs. International Journal of Multiple Research Approaches, 3, 34-46. http://dx.doi.org/10.5172/mra.455.3.1.34

[56] Creswell, J. W. (2011). Controversies in Mixed Methods Research. In N. Denzin, \& Y. S. Lincoln (Eds.), The Sage Handbook of Qualitative Research (4th ed., pp. 269-283). Thousand Oaks, CA: Sage Publications.

[57] Austin Igwe Iyade (2006) the Impact of Regulation and Supervision on the Activities of Banks in Nigeria, PhD Thesis, September, 2006, pp. 211-212. 